M. Piskunov, V. Kudryashov, O. Filippenkov

Ivan Kozhedub Kharkiv National Air Force University, Kharkiv

\title{
A PRIVATE MODEL FOR DETERMINING THE EFFICIENCY OF TARGET DISTRIBUTION
}

A specific model has been developed to assess the performance indicators of target designation when setting obstacles by the enemy and maneuvering various targets. On the basis of the adopted technical characteristics and parameters of stations and weapon systems, optimal target designation options were found. Favorable conditions for firing rockets have also been determined. The indicator of the increase in the average number of destroyed targets is calculated when moving from one type of target placement to another. The course of solving a specific model is presented. Analytical expressions for calculating target indicators of placement efficiency and graphic material are given.

Keywords: target, signal-to-noise ratio, effective scattering surface, interference, range, probability of correct detection, mathematical expectation, centralized distribution of targets, decentralized distribution of targets.

\section{Introduction}

Problem Statement. To maintain high efficiency of target allocation (TA), it is necessary to estimate in real time the mathematical expectation (ME) of the number of destroyed targets [1-3]. In this case, it is necessary to take into account the technical characteristics and parameters of stations and weapons systems, the setting of interference to opponents and the maneuvering of various targets. Currently, there is no particular model that allows you to determine the ME of the number of targets destroyed, taking into account the technical characteristics of weapons elements when countering the enemy with rocket firing and fire control. Therefore, the task of justifying the TA option in the unit is relevant and important.

Analysis of the last Publications. That are presented in the literature [1-5] does not make it possible to determine the $\mathrm{ME}$ of the number of destroyed targets with fixed technical characteristics of weapons elements. The above literature provides general approaches to solving this problem.

The research aims and objectives. To develop a private model for calculating the quality indicator of the TA in the form of determining the ME of the number of targets destroyed for various types of TA, as well as to substantiate the directions for the refinement of stations and weapon systems.

\section{Statement of basic materials}

The indicator of the effectiveness of TA is the ME of the number of destroyed targets [1-3]. Let's consider two types of target allocation - centralized TA (CTA) and decentrolyzed TA (DTA). With a CTA, one target is served by one (or more) combat vehicles (CV) according to TA from the senior commander. When DTA is used, then (CV) chooses the target independently, without using any rules [1-3]. Determination (ME) of the number of destroyed targets $\mathrm{L}$ when firing $\mathrm{m}(\mathrm{CV})$ with a salvo and DTA in the unit.

Calculation of the required detection range of a radar station (radar) $R_{d}\left(r_{d}, V\right)$ in conditions of interference, to implement the greatest slant range to the far border of the affected area (FBAA) $r_{d}$, if the parameter and target flight altitude is not more than $10^{3} \mathrm{~m} \mathrm{[6-7].}$

$$
R_{d}\left(r_{d}, V\right) \approx r_{d}\left(1+1,75 \times 10^{-3} V\right)+V\left(7+\tau_{d}+\tau_{a t}\right),
$$

where $V$ - target flight speed (chosen an average value of $230 \mathrm{~m} / \mathrm{s}) ; \tau_{d}, \tau_{a t}-$ under the condition of the influence of high-intensity interference, the target detection time (30 s) and the time for taking it to auto-tracking (AT) (35 s), respectively.

Received for the middle of the zone affected (ZA) of the complex $R_{d}\left(6 \cdot 10^{3} ; 230\right) \approx 24 \cdot 10^{3} \mathrm{~m}$.

Signal-to-noise ratio $(\mathrm{s} / \mathrm{n})$ for the radar channel of the $(\mathrm{CV})$ reconnaissance radar $q_{d}(\sigma, R, \Delta)$ and the probability of correct detection of various air targets $P_{d}(\sigma, R, \Delta)[6 ; 8-10]$.

$$
\begin{gathered}
q_{d}(\sigma, R, \Delta)=2\left[\frac{P_{p} \tau_{p} G^{2} \lambda^{2} \sigma}{(4 \pi)^{3} R^{4}(1+\Delta) k T_{0}\left(\mathrm{~K}_{n}+t_{a}-1\right)}-B\right] \\
G=32 \cdot 10^{3} /\left(\Theta_{\beta} \Theta_{\varepsilon}\right) ; \\
P_{d}(\sigma, R, \Delta)=F\left(1+\frac{q_{d}(\sigma, R, \Delta)^{2}}{2}\right)^{-1},
\end{gathered}
$$

where $P_{p}, \tau_{p}-$ respectively, the pulse power of the transmitting device and its pulse duration;

$G$ - coefficient radar antenna gain $(\mathrm{CV})$; 
$\Theta_{\beta}, \Theta_{\varepsilon}$ - respectively, the FWHM directional patterns of the radar antenna in azimuth $\beta$ and elevation $\varepsilon$;

$\lambda, \sigma$ - the radar wavelength and effective scattering surface (ESS) of the target, respectively $B, R$ - losses in $\mathrm{CV}$ radar and target range;

$\Delta$ - the ratio of the interference power (residual interference after compensation) to the intrinsic noise of the radar channel;

$k, T_{0}$ - Boltzmann constant and absolute temperature, respectively;

$\mathrm{K}_{n}, t_{a}$ - the noise figure of the radar radio receiver and the relative noise temperature of its antenna, respectively;

$F$ - constant false alarm level of the radar channel of the radar $(\mathrm{CV})$.

Moreover $q_{d}(\sigma, R, \Delta) \geq 0$. Accepted $P_{p}=3 \cdot 10^{5}$ Watt, $\tau_{p}=0,41 \cdot 10^{-6} \mathrm{~s}, \quad \Theta_{\beta} \approx 1,7^{\circ}, \quad \Theta_{\varepsilon} \approx 4,2^{\circ}$, $\lambda=4 \cdot 10^{-2} \mathrm{~m}$, ESS typical target (TT) $\sigma_{t t}=1 \mathrm{~m}^{2}$; $\Delta=16$ times (interference strong power); $k=1,38 \cdot 10^{-23} \mathrm{~J} /$ degree.; $\quad T_{0}=300 K ; \quad \mathrm{K}_{n}=7$; $t_{a}=0,33, \quad F=10^{-2}$. Received for TT $P_{p}\left(1 ; 35 \cdot 10^{3} ; 0\right)=0,5$ and with a small ESS target $P_{d}\left(0,22 ; 24 \times 10^{3} ; 0\right) \approx 0,5$, and with interference $P_{d}\left(1 ; 17,2 \times 10^{3} ; 16\right) \approx 0,5$.

Conditional probability of hitting a target in conditions of enemy countermeasures $R_{l}\left(\xi_{\Sigma}\right)[1 ; 5 ; 11]$.

$$
R_{1}\left(\xi_{\Sigma}\right)=\xi_{\Sigma} \mu_{f r} \varsigma_{z} P_{z} R_{1}
$$

where $\xi_{\Sigma}=\xi_{S} \xi_{c} \xi_{r f}$ the product of the immunity coefficients of the guidance station $\xi_{s}$, missile control loop $\xi_{c}$ and radio fuse $\xi_{r f}$ respectively;

$\mu_{f r}-$ fitness coefficient of the complex when firing at a maneuvering target;

$\varsigma_{z}, P_{z}-$ accordingly, the probability of the missile not being hit enemy during and the reliability coefficient of the missiles combat;

$R_{1}-$ conditional probability of hitting a Typical Target.

To the middle of the affected area Range $=6 \cdot 10^{3} \mathrm{~m}$. To the middle of the affected area Range when there is no channel interference $\left(\xi_{f r}=1\right)$ we have $\xi_{\Sigma} \approx 0,7$ and at $D=10^{4} \mathrm{~m} \quad\left(\xi_{f r}=1\right)$ received $\xi_{\Sigma} \approx 0,37$. When interference affects all systems of a combat vehicle and missiles with interference power $10^{-4} \mathrm{Watt} / \mathrm{MHz}\left(\xi_{f r} \neq 1\right)$ and $D=6 \cdot 10^{3} \mathrm{~m}$ we have $\xi_{\Sigma} \approx 0,39$ and $D=10^{4} \mathrm{~m}-\xi_{\Sigma} \approx 0,2$. Accepted [5;11] $\mu \approx 0,74$ (target makes overload maneuvers $4 g$ ), $\varsigma_{z}=0,94, P_{z}=0,995$ and $R_{1}=0,9$ (the middle of the Complex's Defeat Zone) eventually $R_{1}(0,7) \approx 0,43$ and $R_{1}(0,2)=0,13$.

Expected value number of targets destroyed $M_{d}\left(L, \xi_{\Sigma}, \sigma, D, \Delta, m\right)$ with a lot of air targets and decentralized target distribution [1-2].

$$
\begin{gathered}
M_{d}\left(L, \xi_{\Sigma}, \sigma, D, \Delta, m\right)= \\
=L-L\left\langle 1-\frac{R_{l}\left(\xi_{\Sigma}\right)}{L} \cdot\left\{1-\left[1-P_{d}(\sigma, D, \Delta)\right]^{L}\right\}\right\rangle^{m} .
\end{gathered}
$$

In fig. 1 shows the results of numerical simulation of the values $M_{d}\left(L, \xi_{\Sigma}, \sigma, D, \Delta, m\right)$.

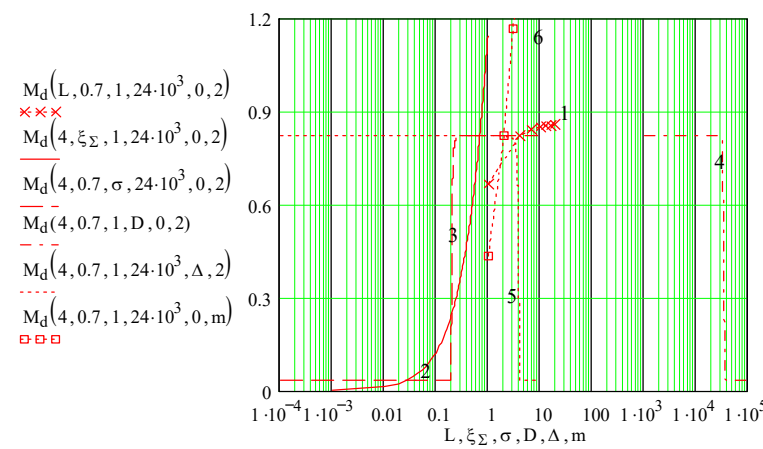

Fig. 1. The number of targets destroyed $M_{d}\left(L, \xi_{\Sigma}, \sigma, D, \Delta, m\right)$ with a lot of air targets and decentralized target distribution Source: developed by the authors.

First curve $1(\cdot \times \cdot \times \cdot \times \cdot \cdot)$ is obtained for different $\mathrm{L}$ and has saturation, since $m=2$. The second curve 2 (continuous) is plotted when the level of interference in the stations and systems of the combat vehicle (missile) changes, and in the absence of interference, the mathematical expectation is greatest. The third curve 3 (- - - -) and the fourth curve 4 (.--.--.-.) show the effect of effective target area and range, respectively. The restrictions on these curves are related to the adopted technical characteristics of the reconnaissance radar of the combat vehicle. The fifth curve 5 (.....) and the sixth curve $6(\bullet$ •• ••) are calculated in the presence of interference on the reconnaissance radar of a combat vehicle and for a different number of combat vehicles, which must reflect an enemy strike, respectively.

To assess the unintended consumption of missiles with decentralized target assignment, we find the probability of shelling one target $k(\mathrm{CV}) P_{k}(L, m)$ [1-2].

$$
\begin{gathered}
P_{k}(L, m)=C(m, k)\left(L^{-1}\right)^{k}\left(1-L^{-1}\right)^{(m-k)} ; \\
C(m, k)=m ! /[k !(m-k) !],
\end{gathered}
$$

where $C(m, k)-$ binomial coefficients. 
Respectively $\quad P_{k}(2 ; 2)=0,25, \quad P_{k}(4 ; 2)=0,06$ and $P_{k}(8 ; 2)=0,016$ or when $L>2 m$ the probability of missiles being misused is rather small. The latter is a significant advantage of using decentralized target distribution. The obtained results of numerical modeling indicate the high efficiency of firing missiles with DTA, at various air targets, in conditions of interference and their maneuvering.

Determination of the mathematical expectation of the number of destroyed targets $\mathrm{L}$ when firing $\mathrm{m}$ combat vehicles with a large number of air raids and centralized target distribution in a subunit. Calculation of the required radar detection range of the senior chief $D_{\text {rad }}\left(r_{d}, V\right)$ in conditions of interference, for the implementation of the greatest slant range to the Far border of the spawn zone $r_{d}$, when the parameter and target flight altitude are not more $10^{3} \mathrm{~m} \mathrm{[6-7].}$

$$
\begin{gathered}
D_{\text {radar }}\left(V, r_{d}\right) \approx r_{d}+V\left[\tau_{\text {radar }}+\tau_{c c p}+\tau_{k c p}+\right. \\
\left.+\tau_{p p s}+\tau_{d p s}+\tau_{s r}+\tau_{d}\left(r_{d}\right)\right] ; \\
\tau_{d}\left(r_{d}\right) \approx 2,5+1,75 \cdot 10^{-3} r_{d},
\end{gathered}
$$

where $\tau_{\text {radar }}-$ the working hours of the senior chief's radar operators;

$\tau_{c c p}, \tau_{k c p}$ - working hours of the command post of the regiment $(\mathrm{CCP})$ and battery command post $(\mathrm{KCP})$ respectively;

$\tau_{p p s}, \tau_{d p s}-$ time of preliminary and immediate preparation of shooting $(\mathrm{CV})$;

$\tau_{s r}, \tau_{d}$ - the delay time of the launch of the missile and its flight to the far border of the affected area of the complex.

Adopted $[2 ; 6-7]$ under conditions of strong interference $(\Delta=16$ times $)$ by radar, $\mathrm{CCP}$ and $\mathrm{KCP}$ : $\tau_{\text {radar }} \approx 57 \mathrm{~s}, \quad \tau_{c c p} \approx \tau_{k c p} \approx 40 \mathrm{~s}, \quad \tau_{p p s}=0 \mathrm{~s} \quad(\mathrm{CV}$ in readiness number 1$), \tau_{d p s} \approx 68 \mathrm{~s}, \tau_{s r} \approx 1,5 \mathrm{~s}$. Received for the middle affected area of the complex $D_{\text {radar }}\left(230 ; 6 \cdot 10^{3}\right) \approx 56,5 \cdot 10^{3} \mathrm{~m}$.

Similar to the expressions in (2), the signal-tonoise ratio in the radar channel of the radar station senior chief $q_{S}(\sigma, D, \Delta)$ and the probability of correct target detection $P_{S}(\sigma, D, \Delta)$ are equal $[5 ; 8-10]$ :

$$
\begin{gathered}
=2\left[\frac{q_{S}(\sigma, D, \Delta)=}{(4 \pi)^{3} D^{4}(1+\Delta) k T_{0}\left(\mathrm{~K}_{n}+t_{a}-1\right)}-B\right], \\
G=32 \cdot 10^{3} /\left(\Theta_{\beta} \Theta_{\varepsilon}\right), \\
P_{S}(\sigma, D, \Delta)=F^{\left(1+\frac{q_{s}(\sigma, D, \Delta)^{2}}{2}\right)^{2}} .
\end{gathered}
$$




$$
\begin{gathered}
A(L, \sigma, D, \Delta, m)=\sum_{\eta=0}^{m-1}\left\{(m-\eta) C(L, \eta) P_{v}(\sigma, Д, \Delta)^{\eta} \times\right. \\
\left.\times\left[1-P_{v}(\sigma, D, \Delta)\right]^{(L-\eta)}\right\} ; \\
C(L, \eta)=L ! /[\eta !(L-\eta) !] ; \\
M_{t}\left(L, \xi_{\Sigma}, \sigma, D, \Delta, m\right)= \\
=\mid \begin{array}{rll}
R_{1}\left(\xi_{\Sigma}\right)[m-A(L, \sigma, D, \Delta, m)] \quad \text { if } \quad L>m ; \\
L P_{v}(\sigma, D, \Delta) R_{1}\left(\xi_{\Sigma}\right) & \text { if } \quad L \leq m .
\end{array}
\end{gathered}
$$

When $L=1, \xi_{\Sigma}=0,7, \sigma=1 m^{2}$, at centralized target allocation $\mathrm{D}=56,6 \cdot 10^{3} \mathrm{~m}$ and with decentralized allocation $D=56,6 \cdot 10^{3} \mathrm{~m}, \quad \Delta=0, \quad m=2 \quad$ got $M_{t i} \approx 0,42 t$ and $M_{d i} \approx 0,67 t$. If $L=1$, and the rest of the indicators are the same $-M_{t i} \approx 0,87 t$ and $M_{d i} \approx 0,82 t$. Deterioration of shooting conditions when $\xi_{\Sigma}=0,2$ will lead $M_{t i}=0,248 t$ and $M_{d i}=0,244 t$. With the accepted technical characteristics and parameters of the radar, combat vehicle and missile, a decrease in the effective spreading area, for example, to $0,56 m^{2}$ gives $M_{t i} \approx 0,44 t$ and $M_{d i} \approx 0,82 t$. Jamming over the radar channels of the senior chief's reconnaissance radar and the CV reconnaissance radar significantly reduces the effectiveness $M_{t i}=0,017 t$ and $M_{d i}=0,034 t$. The latter leads to the need to improve anti-jamming radar reconnaissance. An increase in the number of $\mathrm{CV} m$ to 4 leads to $M_{t i} \approx 1,67 t$ and $M_{d i} \approx 1,47 t$ although when $m=8$ $M_{t i} \approx 1,67 t$ and $M_{d i} \approx 2,4 t$. The latter is explained by the possibility of concentrating fire of several BM, when working on one target and decentralized targeting.

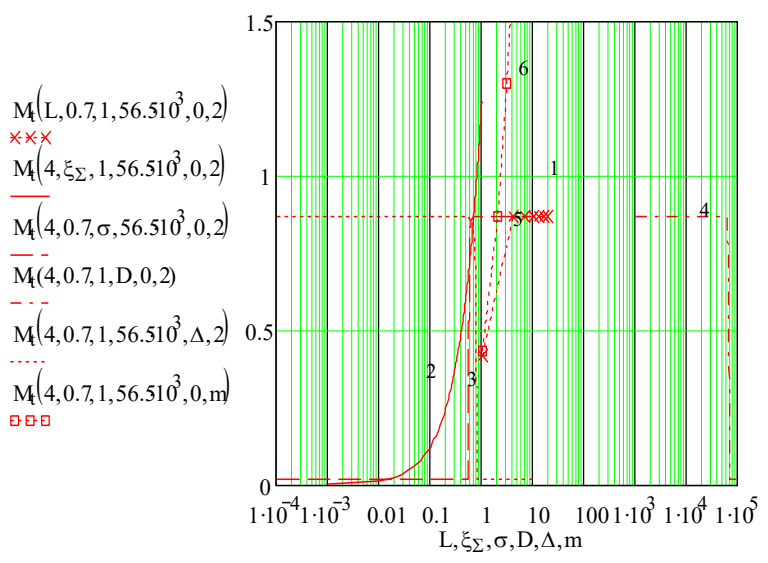

Fig. 2. Expected value of the number of destroyed targets $M_{t}\left(L, \xi_{\Sigma}, \sigma, D, \Delta, m\right)$ in a salvo and centralized target allocation Source: developed by the authors.

Determination of the growth rate of the average number of destroyed targets during the transition from decentralized to centralized in the unit.

To implement the meeting point of the missile with the target in the middle of the affected area of the complex (as calculated above) and the decentralized detection range of the reconnaissance radar of the combat vehicle must be $\sim 24 \cdot 10^{3} \mathrm{~m}$, and at centralized $\sim 56,5 \cdot 10^{3} \mathrm{~m}$. Then the indicator of the increase in the average number of destroyed targets during the transition from decentralized to centralized in the unit $\Delta M\left(L, \xi_{\Sigma}, \sigma, \Delta, m\right)$ is equal [1-2]:

$$
\begin{gathered}
\Delta M\left(L, \xi_{\Sigma}, \sigma, \Delta, m\right)= \\
=M_{d}\left(L, \xi_{\Sigma}, \sigma, 24 \cdot 10^{3}, \Delta, m\right)- \\
-M_{t}\left(L, \xi_{\Sigma}, \sigma, 56,5 \cdot 10^{3}, \Delta, m\right) .
\end{gathered}
$$

In fig. 3 shows the results of numerical simulation of the values $\Delta M\left(L, \xi_{\Sigma}, \sigma, \Delta, m\right)$.

When the increment $\Delta M_{i}>0$ it is necessary to use decentralized target distribution, and if $\Delta M_{i} \leq 0$ - centralized target allocation. For any $L$, besides $L=1$, and $m=2$ it is advisable to use centralized target allocation in the absence of interference through the channels of the reconnaissance radar of the $\mathrm{CV}$ and the radar station of the senior chief (the first curve in Fig. $3, \bullet \times \bullet \times \bullet \times$ $\bullet \bullet$. If the enemy's resistance is insignificant in $\mathrm{CV}$ $\left(\xi_{\Sigma}>0,2\right)$, then we introduce centralized targeting, otherwise any type of TA (second curve, continuous). Before $\sigma \sim 0,5 m^{2}$ - decentralized target allocation, and when $\sigma>0,6 m^{2}$ - CTA (third curve, dash), which is explained by the adopted technical characteristics of the radar. Virtually no interference $(\Delta<0,6)-$ CTA, when $\Delta$ equally 0,7 and more - DTA (fourth curve, dots and dashes). If $L \geq m$ then CTA, and when $L<m-$ DTA in the department (fifth curve, $\bullet \square \bullet \square \bullet \bullet \bullet \square \bullet \bullet$ ).

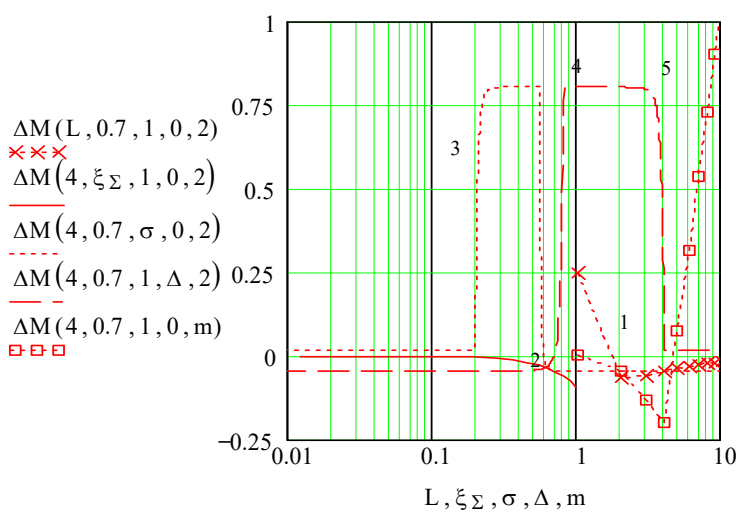

Fig. 3. The rate of increment during the transition from decentralized to centralized in the unit $\Delta M\left(L, \xi_{\Sigma}, \sigma, \Delta, m\right)$

Source: developed by the authors. 
In general, the dependence of the TA efficiency on the technical characteristics and parameters of the radar, $\mathrm{CV}$, missile and enemy countermeasures is shown. The conditions under which it is preferable to apply a CTA or DTA in a department are presented.

\section{Conclusion}

The necessity of the analysis at the CCP (KCP) of the values of $L, \xi_{\Sigma}, \sigma, \Delta, m$ and $m$ for each battery (CV) is substantiated for making an effective decision at CP $[3 ; 12]$.

The implementation of anti-jamming (multi-range) radars, combat vehicles, missiles and those with sufficient energy potential will provide effective firing at small targets [9; 13-15].

The use of non-traditional sound signals, with diversity reception, will also increase the effectiveness of targeting and rocket firing [16].

\section{References}

1. Основы стрельбы и управления огнем войсковых зенитных ракетных комплексов / В.З. Казачинский и др. К.: КВАИУ, 1971. -468 с.

2. Кудряшов В.С. Основи стрільби та керування вогнем / В.С. Кудряшов, С.Г. Леушин, В.І. Самоквіт. - Х.: ХУПС, 2016. $-232 \mathrm{c}$. $556 \mathrm{c}$.

3. Пушкорис В.П. Управление огнем войск ПВО Сухопутных войск / В.П. Пушкорис. - К.: ВА ПВО СВ, 1989. -

4. Довідник з протиповітряної оборони / А.Я. Торопчин та ін. - К.: МО України, 2003. - 368 с.

5. Коломійцев О.В. Модель протиповітряного бою як елемент системи управління вогнем підрозділами військ ППО Сухопутних військ / О.В. Коломійцев // Збірник наукових праць Державного науково-дослідного інституту випробувань і сертифікації озброєння та військової техніки. - 2019. - № 1(1). - С. 94-101.

6. Бойова робота на ЗРК ”Оса-АКМ” / І.Я. Загоруйко та ін. - Х.: ХУПС, 2011. - 140 с.

7. Ширман Я.Д. Теория и техника обработки радиолокационной информации на фоне помех / Я.Д. Ширман, В.Н. Манжос. - М.: Радио и связь, 1981. - 416 с.

8. Ширман Я.Д. Радиоэлектронные системы: Основы построения и теория: справочник. Изд. 2-е, перераб. и доп. / Я.Д. Ширман. - М.: Радиотехника, 2007. - 512 с.

9. Справочник по радиолокации Т. 1 / под общей ред. К.Н. Трофимова. - М.: Сов. радио, 1976. - 456 с.

10. Умовна імовірність ураження цілі з врахуванням надійності роботи елементів комплексу і протидії стрільби ракетами / О.В. Коломійцев, В.С. Кудряшов, О.О. Адамовскій, А.А. Коротя // Збірник наукових праць Харківського університету Повітряних Сил. - 2014. - № 1(38). - С. 3-9.

11. Піскунов С.М. Перспективна структура системи управління силами і засобами протиповітряної оборони Сухопутних військ / С.М. Піскунов. - Збірник наукових праць Харківського університету Повітряних Сил. - 2013. - № 2(35). - C. 6-10.

12. Математическое моделирование взрывательного устройства / А.Б. Скорик, М.І. Камчатний, М.I. Рожков, М.В. Кусяк // Наука і техніка Повітряних Сил Збройних Сил України. - 2014. - № 2(15). - С. 86-89.

13. Shevchenko A.F. A comparative analysis of directional properties of phased ring arrays to be used in multistatic active/passive radars / A.F. Shevchenko // Data Processing Systems. - 2014. - № 9(125). - P. 65-72.

14. Leonov I.L. Estimating receiver performance through PC simulation / I.L. Leonov, A.E. Prisyazhny, D.S. Sidorenko // Data Processing Systems. - 2014. - № 1(117). - P. 30-32.

15. Multi-channel reception system for radiometry signals / V. Kudryashov, D. Litochenko, O. Filippenkov // IEEE Ukrainian Microware Week. - Kharkiv, 21-23 September 2020. - P. 318-322.

16. Kudryashov V.V. A Modified Maximum Likelihood Method for Estimation of Mutual Delay and Power of Noise Signals by Bistatic Radiometer / V.V. Kudryashov // Comptes Rendus del L'Académie Bulgare des Sciences. - 2015. - № 68(5). - P. 631-640.

17. Kudryashov V.E. A Bistatic Radiometry System for Object Mapping / V.E. Kudryashov // Telecommunications and Radio Engineering. - 2018. - № 77(20). - P. 1813-1826. https://doi:10.1615/ Telecom RadEng. v77.i20.40.

\section{Відомості про авторів:}

\section{Піскунов Микола Станіславович}

курсант

Харківського національного університету

Повітряних Сил ім. І. Кожедуба,

Харків, Україна

https://orcid.org/ 0000-0002-5511-0800

\section{Information about the authors:}

\author{
Mikola Piskunov \\ Cadet \\ of Ivan Kozhedub Kharkiv \\ National Air Force University, \\ Kharkiv, Ukraine \\ https://orcid.org/ 0000-0002-5511-0800
}


Кудряшов Віктор Свгенович

кандидат технічних наук

старший науковий співробітник доцент

Харківського національного університету

Повітряних Сил ім. І. Кожедуба,

Харків, Україна

https://orcid.org/ 0000-0002-7055-5357

Філіппенков Олексій Володимирович

ад'юнкт

Харківського національного університету

Повітряних Сил ім. І. Кожедуба,

Харків, Україна

https://orcid.org/0000-0002-4027-6963
Viktor Kudryashov

Candidate of Technical

Sciences Senior Research

Senior Lecturer of Ivan Kozhedub Kharkiv

National Air Force University,

Kharkiv, Ukraine

https://orcid.org/ 0000-0002-7055-5357

Olexii Filippenkov

Doctoral Student

of Ivan Kozhedub Kharkiv

National Air Force University,

Kharkiv, Ukraine

https://orcid.org/0000-0002-4027-6963

\section{ПРИВАТНА МОДЕЛЬ ВИЗНАЧЕННЯ ЕФЕКТИВНОСТІ ЦІЛЕРОЗПОДІЛУ В УМОВАХ ПРОТИДІЇ ПРОТИВНИКА}

М.С. Піскунов, В.С. Кудряшов, О.В. Філіппенков

Розроблена часткова модель для оцінки показників ефективності ијілерозподілу при постановці противником перешкод і маневруванні різних иілей. На основі прийнятих технічних характеристик $і$ параметрів станцій $і$ систем озброєння знайдені кращі варіанти цілерозподілу. Також визначені сприятливі умови для стрільби ракетами. Наводяться значення математичного сподівання (MC) числа знищених цілей при стрільбі декількома бойовими маминами (БМ) при залповому нальоті і децентралізованому циілерозподілу (ДЦР) в підрозділі. Знайдено необхідні дальності виявлення радіолокаиійної станції (РЛС) БМ в умовах перешкод сильної інтенсивності. Для реалізації найбільшої похилої дальності до дальньої межі зони ураження взяли, щзо параметр і висота польоту иілі не більше $10^{3}$ м. 3 а типовими технічними характеристиками і параметрами РЛС БМ розраховані відномення сигнал-шум в радіолокаційному каналі $i$ ймовірності правильного виявлення різних повітряних иілей в умовах протидї супротивника. Для вирімення завдань стрільби і управління вогнем знайдені значення умовних ймовірностей влучення в ціль в умовах перешкод при маневруванні та вогневій протидї по ракеті. Проведено аналіз умов, при яких знижується ймовірність нецільової витрати ракет при ДЦР в підрозділі. Отримані результати чисельного моделювання показали високу ефективність стрільби ракетами при ДЦР по різних повітряних цілях в умовах перешкод і при можливому маневруванні цілей $і$ вогневій протидії. За аналогією з рішенням завдання при ДЦР отримані значення МС числа знищених иілей при централізованому цүілерозподілу (ЦЦР) в підрозділі. Розрахований показник приросту середньої кількості знищених иілей при переході від ДЦР до ЦЦР. Показані умови, при яких слід застосовувати ДЦР або ЦЦР в підрозділі. Наводяться показники, які належить аналізувати на командному пункті для вибору найкращого виду иілерозподілу. Представлений хід рімення часткової моделі. Наведено аналітичні вирази розрахунку показників ефективності иілерозподілу і графічний матеріал.

Ключові слова: мета, відношення сигнал-шум, ефективна поверхня розсіювання, перешкоди, дальність, ймовірність правильного виявлення, математичне очікування, централізований цฺілерозподіл, децентралізований ціілерозподіл.

\section{ЧАСТНАЯ МОДЕЛЬ ОПРЕДЕЛЕНИЯ ЭФФЕКТИВНОСТИ ЦЕЛЕРАСПРЕДЕЛЕНИЯ В УСЛОВИЯХ ПРОТИВОДЕЙСТВИЯ ПРОТИВНИКА}

\section{Н.С. Пискунов, В.Е. Кудряшов, А.В. Филиппенков}

Разработана частная модель для оценки показателей эффективности целераспределения при постановке противником помех и маневрировании различных целей. На основе принятых технических характеристик и параметров станций и систем вооружения найдены лучшие варианты иелераспределения. Также определены благоприятные условия для стрельбы ракетами. Рассчитан показатель приращения среднего количества уничтоженных иелей при переходе от одного вида иелераспределения к другому. Представлен ход решения частной модели. Приведены аналитические выражения расчета показателей эффективности иелераспределения и графический материал.

Ключевые слова: иель, отношение сигнал-иум, эффективная поверхность рассеивания, помехи, дальность, вероятность правильного обнаружения, математическое ожидание, иентрализованное иелераспределение, децентрализованное целераспределение. 